\title{
Towards Franchising Mobilization Strategy in Large-Scale Energy Efficiency Retrofit Industry
}

\author{
Maryam Mirhadi Fard ${ }^{1,2}$, Charles J. Kibert ${ }^{1,2} \&$ Seyyed Amin Terouhid ${ }^{1}$ \\ ${ }^{1}$ M.E. Rinker Sr. School of Building Construction, University of Florida, Gainesville, Florida, USA \\ ${ }^{2}$ Powell Center for Construction and Environment, University of Florida, Gainesville, Florida, USA \\ Correspondence: Maryam Mirhadi Fard, M.E. Rinker Sr. School of Building Construction, University of Florida, \\ 304 Rinker Hall, Gainesville, FL 32611, USA. Tel: 1-352-273-1182. E-mail: mirhadi@ufl.edu
}

Received: June 1, 2012 Accepted: July 4, 2012 Online Published: July 9, 2012

doi:10.5539/jsd.v5n8p1

URL: http://dx.doi.org/10.5539/jsd.v5n8p1

\begin{abstract}
Implementing large-scale energy retrofit projects for reducing residential energy consumption requires large scale mobilization and training of contractors with the appropriate skill sets for carrying out the retrofits. General contractors, one of the key parties in these types of projects, play a crucial role in facing the challenge of large-scale, national level mobilization. Most retrofit projects are performed in a fragmented manner, that is, a small percentage of contractors undertake executing all the retrofit tasks, and other contractors, typically trade subcontractors, prefer to operate only in their specific fields of proficiency. In addition, most general contractors operate in very geographically specific markets, limiting their market share and access. We propose a transition step in the conduct of energy efficiency retrofits by adopting a franchising business model as a leveraging strategy for general contractors in the retrofit industry. This study is being carried out to investigate the conceptual and practical benefits of franchising a mobilization option for large-scale energy retrofit industry. Based on the nature of this industry, a practical franchising arrangement is also proposed for this sector.
\end{abstract}

Keywords: energy retrofit industry, energy efficiency, franchising structure, mobilization strategy, SWOT analysis

\section{Introduction}

Limited natural resources and increasing energy consumption have resulted in the development of appropriately focused energy policies such as residential energy efficiency retrofit programs. Efforts aiming at reducing energy consumption by American homes date back to before World War II. At that time, the Massachusetts Institute of Technology (MIT) conducted studies on solar heated structures, leading to the construction of four research structures, ending with the MIT Solar House IV built in 1958-1959 with $60 \mathrm{~m}^{2}$ of solar collectors (Parker, 2009).

The sharp increase in oil prices between October 1973 and January 1974 reinforced concerns about natural resource depletion and the environment. This energy shock resulted in the next wave of energy conservation efforts (Hollander \& Schneider, 1996; Parker, 2009). According to Kibert (2003), the oil shock resulted in greatly increased interest in energy efficiency, solar technologies, retrofitting homes with insulation, and energy recovery systems. The federal government also provided tax credits for solar energy investments and technologies. In taking action in response to energy shocks, federal and states governments made building energy use one of their main focus areas.

Based on the US Census Bureau (2010), there are approximately 131 million housing units in the US which account for approximately $23 \%$ of the nation's energy consumption (U.S. Energy Information Administration, 2010). Therefore, improving residential energy systems, such as lighting, heating, cooling, and miscellaneous plug loads, is considered as one of the most effective solutions to significantly reduce energy consumption and has recently received renewed attention from government and building practitioners.

Briefly, in this paper, we have focused on large-scale retrofit projects due to the following reasons:

- Considering the urgency of the need for increasing energy efficiency in existing homes in the United State, the need for well-developed and innovative mechanisms for improving energy efficiency in this sector is urgently needed. 
- In recent years, national investment strategies, such as the American Recovery and Reinvestment Act (ARRA) of 2009, have been developed for this purpose, and are evidence of the increasing urgency for increasing energy efficiency. The ARRA, signed into law as a stimulus plan in 2009, is, at least in part, an investment in increasing the energy efficiency of housing units in the United States. Although the full range of consequences of the ARRA law on the US housing retrofit industry remains to be determined, it is considered as major legislation that significantly increased funding for research and investment for residential energy efficiency and retrofit programs.

However, major programs such as ARRA, while providing significant resources for energy efficiency retrofits, do not address the mobilization of the enormous construction capability needed to carry out these retrofit projects. By conducting a Strengths, Weaknesses, Opportunities and Threats (SWOT) analysis, this paper proposes franchising as a means of mobilizing construction industry for executing large-scale energy efficiency retrofits. In addition, a practical franchising arrangement is proposed for this industry. Based on the conducted literature review, the current study can be regarded as a novel approach toward large scale energy retrofit projects.

\section{The Concept of the Franchising Business Structure}

Franchising is described as a method of distributing services and products in order to grow a business more rapidly than traditional approaches. In franchising, a sponsor enters into a contractual relationship with parties and grants them the right to conduct the business under its trade name for a period of time, in a specific territory, and according to the franchisor's standards and formats. Brickly and Dark (1987) defined franchising as leasing an intangible asset (trademark), so the decision whether to franchise a business or create an owned outlet can be viewed as a buy versus lease decision.

As practiced in other business sections, a franchisor in building energy retrofit projects will be a qualified contractor who is capable of design and construction services. For the purposes of this paper, franchisees are building retrofit general contractors who would start their businesses based on a proven trademark registered by the franchisor. The franchisor establishes all technical and managerial standards, business policies, comprehensive training programs, operating policies, minimum quality standards, quality control procedures, and an accepted certification system suitable for energy retrofit projects. The franchisor grants the franchisee the right to operate its business under the franchisor's name. Franchisees are interested and qualified general contractors chosen by the franchisor based on their experience, proficiency, and financial stability.

Franchising has two distinguishing characteristics that make it different from other structures. First, franchising is usually adopted by businesses that should provide services near customers, and therefore the service providers must be dispersed geographically. Second, in a franchise contract, a centralized company (the franchisor) delegates a unique allocation of responsibilities, decision making, and profits to decentralized agents (franchisees) (Combs et al., 2004).

Franchising can be done through different arrangements and types of relationships. A franchisor can grant a privilege to a franchisee to sell its products or services by using the franchisor's operating methods and standards, or he can give the right to a franchisee just to do the business under his brand name and images or a combination of these. The common issue among all the arrangements is that the franchisor uses an independent party to deliver his services or products to the customers (Axelrad \& House, 1987).

Axelrad and Rudnick (1987) classified franchising models as follows:

- Product distribution franchising: In this type of franchising, a franchisor gives the right to a franchisee to sell its product at a specific location or area. This approach to franchising is common for manufacturers of products, such as automakers, gasoline, tires farm equipment, and auto accessories.

- Business format franchising: In business format franchising, franchisors grant the right to use their trademarks to franchisees along with their operational standards and formats. This type of business involves some key elements, such as quality control, furnishings, equipment, design, furniture, and training. This type of franchising is prevalent in particular industries, such as food, auto repair, consumer service industries, and lodging.

- Conversion or affiliation franchising: In this type of franchising, franchisees are expected to make some changes to the existing business to be in accordance with a common system of marketing. The main attribute is that through a common trademark, marketing, local advertising, training, and economics of purchasing are greatly facilitated. However, in this type of franchising, the franchisor has less power and authority to control 
business uniformity in the entire franchise chain. Conversion franchising has been applied to financial services, floral shops and real estate brokerages.

It is worth mentioning that according to Axelrad and Rudnick (1987), the franchising business in the home remodeling industry falls into the third category, conversion or affiliation franchising.

\subsection{The Sources of Franchisors' Income}

In a franchise business, there are four main sources of revenue for franchisors (Axelrad \& House, 1987; Michael, 1996):

\section{- Initial fees}

At the time of contract signing, the franchisor receives a lump sum payment called the initial fee. Other establishment fees may also include training, equipment, site selection, and leasing real estate.

\section{- $\quad$ Ongoing royalty fees on sales}

Royalty fees are paid to franchisors based on the ongoing services and benefits that the franchisees are utilizing; it is usually calculated based on the percentage of the franchisees' gross income.

\section{- $\quad$ Advertising fees}

Franchisees may agree to pay a type of royalty fee for marketing expenses.

\section{- $\quad$ Transfer fees}

During the time period of franchise agreement, a transfer fee may be required if a franchisee sells the franchised business to another party.

\subsection{The Opportunities and Constraints of Franchising}

Some researchers believe that, due to its extensive benefits and opportunities, franchising has been an excellent approach for some industries, such as restaurants, hotels, and gas stations, to expand their businesses and distribution of their services and products (Axelrad \& House, 1987; Bradach, 1998). In order to choose franchising as the business expansion strategy over owning the business and to effectively operate it, the franchisee should be aware of the following (Axelrad \& House, 1987; Brickley \& Dark, 1987; Caves \& Murphy, 1976; Michael, 1996):

1) The level of business risk in the industry should be low.

2) Point-of-sale quality control, management skills and motivation at units are the key elements of the business.

3) The cost of on-site monitoring and control of a company-owned branch is higher than a franchised one.

4) A large amount of capital investment is required for establishing a franchise.

5) The business should have the potential for generating enough profit.

6) There should be low investment risk on the part of the franchisee.

In general, according to Murray and Smyth (2011), there are two main reasons for companies to approach franchising business structure. The reasons are known as resource scarcity theory and agency theory. Based on resource scarcity theory, franchising structure is selected for company growth when primary investment, managerial skill, or knowledge of local markets is required (Oxenfeldt \& Kelly, 1968). Agency theory states that franchising growth method is selected when the cost of a franchised company is lower that a company-owned branch (Caves \& Murphy, 1976).

\subsubsection{The Benefits and Opportunities of Franchising}

Franchising has a number of benefits and some of these are listed below:

- $\quad$ Franchisees who have better knowledge of local demands and markets are responsible for solving some of the local operating policies, such as salaries, prices, location, human capitals, and planning. Therefore, they can better accommodate the client's requirements and satisfy local demands.

- Through franchising, companies can rapidly acquire local expertise and penetrate the local markets.

- $\quad$ Franchisees with their flexibility and entrepreneurial goals are more likely to find profit opportunities (Demsetz, 1968; Hayek, 1978).

- The familiarity of franchisees with their customers assists the franchisors to become more aware of the customer's needs, enabling them to update their techniques (Alon, 2006). 
- In industries where the supervision cost of a company-owned outlet is high, the franchising strategy is usually selected by the company. Franchisors can eliminate supervision and training on the part of the company. As franchisee's profits and growth are directly influenced by their performance, they are more committed and motivated to run businesses compared to salaried employees. In addition to financial assessment, franchisors regularly evaluate franchisees' performances based on standards and procedures that create uniformity and prevent the potential chaos in the system (Bradach, 1998).

- $\quad$ Franchisors require less staff for monitoring and managing the business.

- $\quad$ As Demsetz (1968) suggested, implementing franchising contracting process by competitive bidding approach can reduce subsequent regulations.

- With limited resources in some industries or lack of capital in some companies, franchising is considered as a rapid growth tool for companies with regard to their size, location and economy. Therefore one of the key benefits of the franchising strategy is the ability to rapidly develop the business and extend the trademark with very low investment and management compared to an owned company.

- $\quad$ Franchisees, with their financial share in the market, are more likely to build and maintain long-term businesses and marketing compared to company-owned outlets.

- $\quad$ Franchising creates local investment and new job opportunities in a growing business.

- $\quad$ Franchising allows small outlets to compete with large firms through a uniform system.

- The decentralized arrangement of franchising decreases the franchisors' risk by transferring the risk to the franchisees and minimizing initial investment.

- A uniform code of ethics and a customer-care training system can be applied to the whole structure.

2.2.2 The Risks and Constraints of Franchising

As is the case with other business structures, the franchising system has constraints and risks that may cause some industries to not consider it as their dominant business system.

1) Due to legal constraints, the franchisor may lose control over the business and be unable to change the business direction.

2) Franchisors may become exposed to franchisees' negligence and failure, which can damage the franchisors' reputation.

3) Franchisors may have difficulties recruiting and retaining qualified franchisees.

4) In some industries, the net profit of a company-owned outlet may exceed that of a franchised firm.

5) In franchising, one of the major problems that most franchisees have faced is territory encroachment by the franchisors. When a franchising system becomes stable, both franchisees and franchisors look for new territory to expand their business so franchisors may infringe the franchisee's territory through an agreement with another franchisee or by establishing a company-owned outlet. One of the territories with no boundary is the internet through which franchisors can gain access to the franchisees' customers directly (Emerson, 2010).

6) By learning franchisors' operation techniques, franchisees may not follow their commitments to franchisors (Davies et al., 2011). Therefore, keeping franchisees satisfied and dedicated to their business can be an obstacle for franchisors.

7) Some conflicts such as timing, income and priorities are common between franchisors and franchisees due to their different goals (Garg \& Rasheed, 2006; Harmon \& Griffiths, 2008).

\subsection{Franchising Structures}

The structural form of an organization has direct impact on its efficiency and outcomes (Botti et al., 2009). The arrangement of a franchised structure is very different from that of an owned-company. The structure of companies is hierarchal in which the performance of employees is monitored and controlled by their managers while the structure of franchising resembles a federal arrangement, reducing the need for franchisors' involvement and control (Bradach, 1998). Table 1 lists some of the characteristics of company and franchise organization. 
Table 1. The characteristics of company and franchise arrangements (Adapted from Bradach (1998))

\begin{tabular}{lll}
\hline Characteristic & Company & Franchise \\
\hline Contractual Relationship & Employee & Partner \\
& Zone of acceptance & Formal contract \\
Chain Operator's Economics & Profits & Fees Royalties \\
Local Operator Rewards & Salary & Net income \\
and Orientation & Internal System & External Market \\
Source of Chain Operator Influence & Authority & Persuasion \\
Architecture of Information & Transparent operation & Opaque operation \\
& "Less-rich" & "Rich" \\
Structural Type & Hierarchy Stable structure & Federation Fluid Structure \\
& People move & People stable \\
\hline
\end{tabular}

\subsubsection{Structure One: Single Form of Franchised Structure}

In this organization, a franchisor expands its business only through franchisees. In this type of arrangement, simultaneously maintaining uniformity, control, and innovation is difficult (see Figure 1).

Some researchers, such as Oxenfeldt and Kelly (1968) and Hunt (1973), believe that many franchisors initially tend to establish franchisees to penetrate the market rapidly, and once they meet their target, they shift their focus to company ownership and efficiency. In other words, they become more concerned about the profitability and managerial control of their retailers after the initial market penetration.

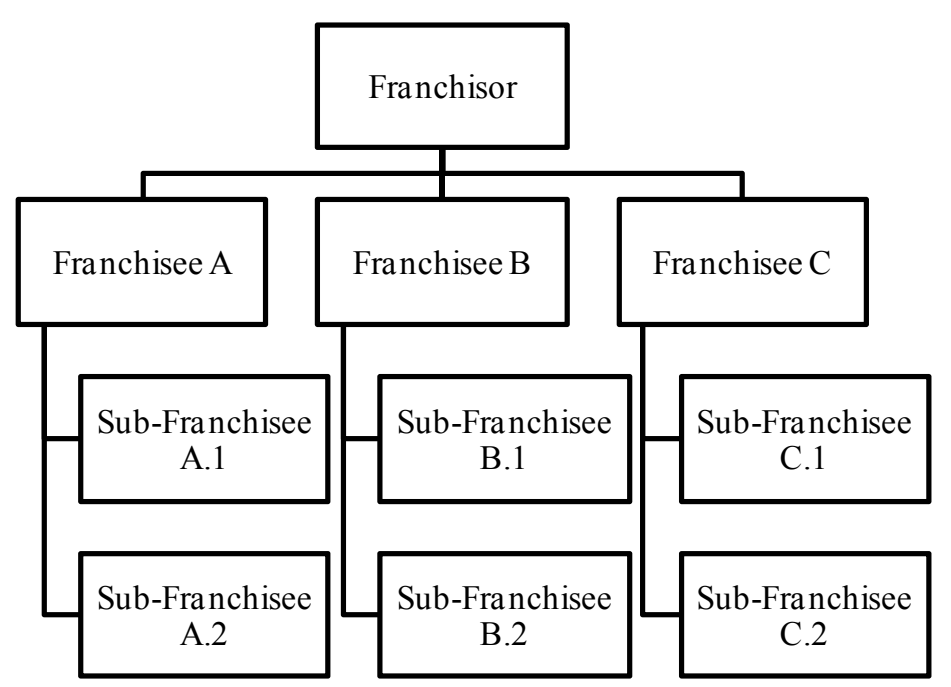

Figure 1. A sample of a single franchised structure

\subsubsection{Structure Two: Plural Form}

The plural organizational form is the simultaneous use of company-owned and franchise arrangements (see Figure 2). Some researchers believe that the plural form structure makes the chain stronger and more efficient. In this structure, franchised and company-owned arrangements complement each other in balancing their weaknesses and strengths (Bradach, 1998). One of the main attributes of the plural form is having both uniformity and innovation, which are difficult to have in a single organization. However, according to Botti (2009), none of the research has measured the impact of the plural form on the efficiency level of the chain compared to the other structure formats. 


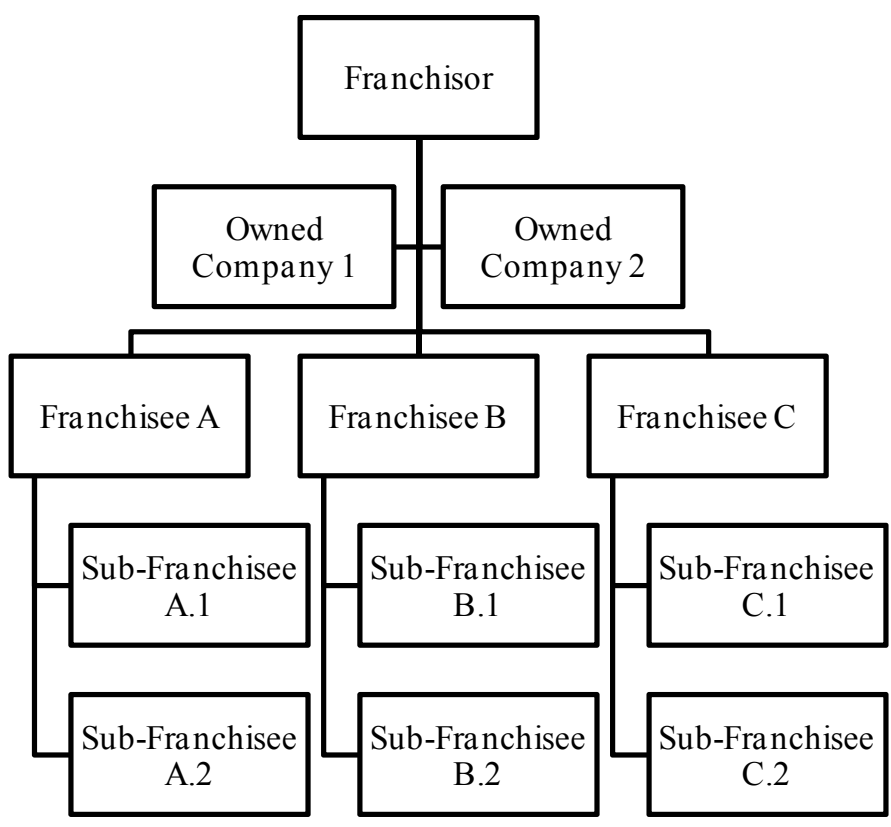

Figure 2. A sample of a plural franchising structure

\section{Franchising in Construction and Building Industry}

To be able to evaluate the efficiency of franchising systems on the output of industries, it is better to study franchising in its industry field (Michael, 1996). However, there are limited franchising studies in construction industry in general and in building industry in particular; and researchers have paid very little attention to this industry.

The research of Fielding and Klein (1993) can be considered as one of the primary franchising research projects in the construction industry. They suggested a method for franchise contracting of highway services. Their proposed method has two main elements. The first one is "Clearing-Before-Awarding", which focuses on acquiring environmental permissions before handing the projects to franchisees. The second one is "Marginal-Return Bidding", which focuses on having competitive approach in franchise contracting process.

Engel et al. (1997) studied the benefits and the risks of implementing franchising in massive highway projects. Watson and Kirby (2000) also made some progress in understanding this industry by evaluating franchising system constraints in the UK construction industry. By conducting interviews with franchisees in the construction sector, Watson and Kirby found that there are few problems in practice.

According to Smyth (2009), franchising approach to construction subcontractors is possibly a lower cost approach compared to construction supply chain management method. He believed that in construction, there are two options in franchising: management option and the man and van option.

Dongmei and Xiaoyun (2009) believed that franchising business model is very suited for the large scale infrastructure projects and public utilities due to sharing risks and revenues between businesses and governments. In their study, Dongmei and Xiaoyun proposed a quality risk management systems for China's franchise projects.

The work of Murry and Smith $(2009 ; 2011)$ is among the limited franchising research studies in building industry in particular. They studied the barriers that general contractors may be faced as a result of using franchising in the remodeling industry. Although, several studies have been conducted regarding the implementation of franchising strategy in the construction and building industry, none of them deals with energy efficiency projects. Therefore, the current study can be regarded as a unique approach in the large-scale energy efficiency retrofit industry.

Entrepreneur provides a list of major operating national franchises in its website. According to the website, 46 franchisors are operating in the US building and remodeling industry. These franchisors have 2,545 franchisees and company-owned outlets. Over $90 \%$ of these franchises are active only in a single trade such as kitchen or bath remodeling. Of these companies, $17 \%$ started franchising before 1990, so they have operated franchising for more than 20 years, and 19\% of them have started franchising between 1990 and 2000. The rest of these 
companies initiated this business strategy after 2000 . The average loyalty fee of these firms is approximately $6 \%$. Interestingly, 26\% of these companies were in the 2011 list of Entrepreneur's top 500 franchises (Entrepreneur, 2011).

\subsection{Constraints of Franchising in Construction}

The challenges of franchising business model vary based on the types of industries. In the literature there are few studies on the difficulties of franchising in different industries. As Watson and Kirby (2000) argued in their paper, there are a few operational difficulties with franchising in construction due to unfamiliarity of construction industry with this business model. According to them, the major difficulty is the recruitment of qualified franchisees. Finding eligible franchisees in different geographic markets who can satisfy clients' needs and have enough technical and managerial experience is difficult.

Murray and Smith (2009) believed that the main barrier to franchising initiation and operation in the remodeling industry is the human capital requirement. It is worth mentioning that the respondents who have been interviewed considered franchising as a feasible "viable growth strategy for general remodelers". In general, Murray and Smith (2009) concluded that the theories of franchising and the data from the remodeling industry show there is no real barrier to the implementation of franchising in the remodeling industry.

\section{Franchising Strategy in the Large-scale Energy Efficiency Retrofit Industry}

Today, more attention is given to energy performance, carbon, and the environmental footprint of buildings and their impacts on the environment. Moreover, after being faced with economic crises, contractors and homeowners are looking for more economical solutions to reduce their long-term expenses and maximize economic resources such as time and budget (McGraw-Hill Construction, 2010).

Successes of energy efficiency retrofit projects are significantly dependent upon the quality control process as part of managerial skills and local market knowledge (e.g. energy retrofit regulations and available green products). Moreover, since energy retrofit projects should be executed in diverse locations, cost of on-site monitoring and quality control will be significant for companies. Therefore, based on resource scarcity and agency theories, and the conducted Strengths, Weaknesses, Opportunities and Threats (SWOT) analysis in this study (see Table 2), the authors believe that franchising can be considered as a potential vehicle for facilitating large-scale energy efficiency retrofit projects. In addition, it is an economical solution for the growth of general contractors in this industry who are primarily responsible for improving the energy performance of buildings, such as improving HVAC systems, insulation, windows, and glass in single-family and multi-family dwellings.

The authors believe that this industry has the potential to embrace franchising as a business strategy. However, due to the novelty of this idea, before making any decision regarding the implementation of this business structure, further investigation should be conducted to study all short-term and long-term risks associated with this idea.

The SWOT analysis was done based on the conducted literature survey, and results were refined based on expert judgments provided by specialists of the built environment.

The followings are some of the potential benefits of implementing a franchising strategy at large-scale for energy efficiency retrofits.

- Currently, most residential retrofit projects, including energy retrofits, are performed in a fragmented manner and only a small percentage of contractors undertake all the required retrofit tasks. The franchising strategy has the capability to rapidly engage significant number of contractors at national scale to mobilize a large-scale energy efficiency retrofit industry.

- Reducing the energy consumption of residential buildings has gained a lot attention from governments, building practitioners, and homeowners, so this industry has the potential for generating good profits for companies, and the risk is not high.

- One of the key success factors of energy retrofit projects is quality control and management. Without franchising, companies are required to take on the burden and significant cost of on-site monitoring and quality control for all their small and large projects.

- Compared to the other types of industries, the risk of initial investment in this industry for franchisees is low. Most of the investments made in employee training, standardization, development of quality systems, and certification will become the tangible and intangible assets of companies in any business structures. Additional equipment may be required for energy retrofit projects. Examples include blower doors with flow plates, duct blasters, digital micro-manometers, and air flow measuring devices (Building Performance Institute, 2008). 
- $\quad$ As explained in more detail in the following section, by involving a third party company in the franchising structure, franchisors can delegate some of the key responsibilities such as quality assurance and end of job certification to this party. Therefore, in terms of services and quality of work, uniformity can be maintained throughout the whole business structure.

- Due to the business nature of the home retrofit industry and the implementation of the proposed franchising structure, if franchisees' physical territories are defined specifically in the contract, the possibility of territory encroachment by franchisors and franchisees is to some extent lower than other industries.

- Customer-care and code of behavior training for contractors is one of the key success factors for energy retrofit projects. This is due to the fact that energy retrofits have long-term impact on encouraging homeowners to reduce energy consumption. By involving a third party in the franchising structure, companies can enhance their employee performance with respect to their customer service.

- In energy retrofit projects, employees are key resources, and having adequate numbers of trained employees based on the organization's goals and market demand is vital for the performance of projects and the success of the business. We believe that franchisees with their local knowledge can proactively gauge the condition of resources and consequently take corrective action, such as on-the-job training, recruitment and screening.

- As mentioned before, a significant percentage of American homes need to be retrofitted for energy efficiency. Therefore, there is a potential high demand and a vast geographical area in which American companies can expand their businesses much easier by franchising. We believe growing a construction business through company-owned outlets will result in higher cost for companies for the following reasons:

1) Companies may not be familiar with the local market.

2) They will have to invest significant effort to review and consider local codes and standards.

3) Compared to franchisees, it takes more time for companies to hire qualified workers due to their unfamiliarity with the local market.

4) Because of long distances, monitoring and control cost, which is inseparable part of these projects, will be higher.

\subsection{Proposed Franchising Structure for Large-scale Energy Retrofit Project}

The nature of large-scale energy retrofit projects is unique compared to other construction projects for the following reasons:

1) The quality of energy retrofit projects will not only affect the understanding of the long-term goals and benefits for these projects, but will also affect public interests for implementing these projects.

2) Continuous training is required for contractors in diverse locations to be familiar with the latest energy efficiency technologies, materials, products, software, and experiences.

3) Contractors have an important responsibility in terms of safety, quality management, training and certification.

4) Customers of energy retrofit services are usually private homeowners with lack of knowledge about the retrofit processes. Moreover, projects usually occur while customers inhabit in the house. Therefore, the level of interaction between homeowners and contractors is high, and it is difficult to manage these projects compared to the construction of new high performance buildings. 
Table 2. SWOT analysis of franchising mobilization strategy in large-scale energy retrofit industry

\begin{tabular}{|c|c|}
\hline \multicolumn{2}{|c|}{ Strengths } \\
\hline S1 & $\begin{array}{l}\text { Low market risk and high potential for making good profits due to the strong support of the } \\
\text { government from this industry }\end{array}$ \\
\hline $\mathrm{S} 2$ & Low cost of on-site monitoring and quality control for franchisors \\
\hline S3 & Uniformity in quality and certification requirements in the chain by involving a third party \\
\hline S4 & Keeping a uniform code of behavior and customer-care by involving a third party \\
\hline S5 & Controlling the level and condition of resources due to local knowledge of franchisees \\
\hline S6 & Available local information \\
\hline \multicolumn{2}{|c|}{ Weaknesses } \\
\hline W1 & Difficulties in recruitment and retention of capable franchisees \\
\hline W2 & $\begin{array}{l}\text { Difficulties in managing the contractual relationships between franchisors, franchisees and third } \\
\text { parties }\end{array}$ \\
\hline W3 & The possibility of too much control over franchisees by third parties \\
\hline W4 & The possibility of quality being sacrificed due to quantity and the speed of work \\
\hline W5 & $\begin{array}{l}\text { Difficulties in defining and managing responsibilities among parties in franchise relationship } \\
\text { structure }\end{array}$ \\
\hline \multicolumn{2}{|c|}{ Opportunities } \\
\hline $\mathrm{O} 1$ & Engaging a significant number of contractors at a national scale \\
\hline $\mathrm{O} 2$ & Low risk of territory encroachment by involving a third party \\
\hline $\mathrm{O} 3$ & Low risk of initial investment for franchisees \\
\hline $\mathrm{O} 4$ & Rapid growth of companies \\
\hline O5 & $\begin{array}{l}\text { Increasing of public interests in these projects due to the strengths of the franchising business } \\
\text { model }\end{array}$ \\
\hline \multicolumn{2}{|c|}{ Threats } \\
\hline $\mathrm{T} 1$ & Novelty of the idea and lack of experience \\
\hline $\mathrm{T} 2$ & Funding shortfalls for homeowners \\
\hline $\mathrm{T} 3$ & $\begin{array}{l}\text { The net profit of a company-owned outlet may be greater than the net profit of a franchised } \\
\text { branch }\end{array}$ \\
\hline $\mathrm{T} 4$ & Investment risks for homeowners due to the risks of investment returns \\
\hline T5 & Challenges involved in handling the cases of dispute among parties \\
\hline
\end{tabular}

Since, large-scale energy retrofit projects have unique nature compared to other projects and the success of a franchise system is directly dependent upon the design and the standards of its network (Davies et al., 2011), the authors have proposed a new franchising structure for energy retrofit projects. The proposed structure was validated based on the judgments of a group of experts in the built environment. In the proposed business arranegment, by involving a professional organization as a third party in the chain,franchisors delegate some of the business tasks such as franchisee qualification, training systems, designing and implementing a quality managemet system and end of job certification to a third party.

In large-scale energy retrofit industry, monitoring and controling franchisees and performed works are inseparble parts of projects. In fact, the quality of projects has significant impacts on the long-term goals of these projects, public interests in these projects, and cost of projects. In addition, too much control over franchisees can discourage them from continuing the business. Therefore, quality management is very crucial in eneregy retrofit industry and can be very difficult in large-scale projects. By inolving a general consultant as a third party, a uniform monitoring system, quality management system, and training and certification system will be 
implemented through the whole chain.Therefore, a higher standard of quality can be guaranteed and the risk of lack of true involvement by franchisees will be significantly reduced.

Through standardization, implementing, and maintaining best practices, the impact of the limitations of human capital on the success of the enterprise can be greatly decreased, thereby reducing concern about adopting franchising for energy efficiency retrofits. Some of the responsibilities that franchisors can delegate to a third party are as follows:

- Establishing a uniform quality management system in the chain

- Qualification and selection of franchisees

- $\quad$ Establishing technical and managerial training system

- $\quad$ Training of key employees

- $\quad$ Specifying procedures by which energy retrofit tasks can be preformed

- $\quad$ Providing end of job certification

- Periodic evaluation of franchisees

- Ongoing training of key people to share information about new developments, new available materials and products and experiences

- Safety and occupational health training of franchisees specifically for energy retrofit projects

Regarding third party fees, franchisors can pay these from their royalty fees or it can be agreed in the contract to be paid by franchisees or to be shared between them (Hunt, 1973). The third party can be selected from current professional organisations who are supporting the development of high performance buildings.

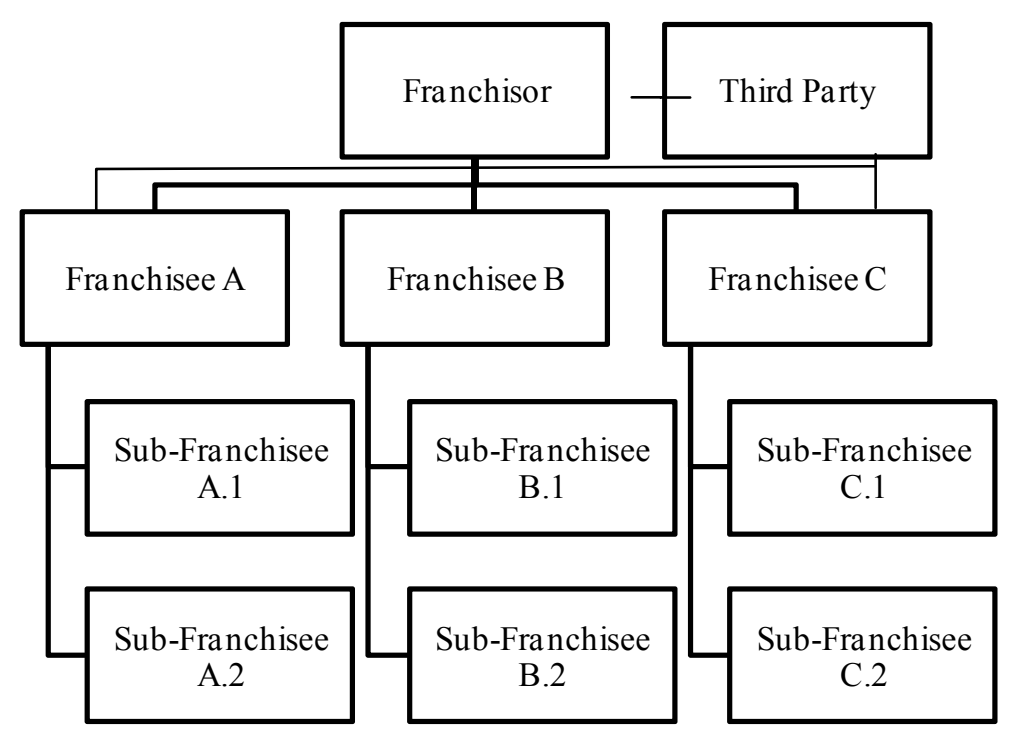

Figure 3. A sample of proposed franchising structure for large-scale energy retrofit project

\section{Conclusion}

In most energy retrofit projects, homeowners rely on contractors to plan and implement the project based on their knowledge and experience. Therefore, contractors are one of the key parties in these projects and play important roles. Contractors must have sufficient knowledge to advise homeowners and incorporate suitable energy efficient measures into the construction plan. In this study, we proposed franchising as a mobilization strategy for residential energy retrofit projects due to its numerous advantages. The suggestion of franchising strategy for residential energy retrofit projects was based on the conducted SWOT analysis. Expert judgments were utilized in conducting the SWOT analysis for building confidence in the results.

After providing a brief snapshot of the franchising concept and its elements, we suggested an applicable franchising arrangement for the energy retrofit industry. In this structure, apart from a franchisor and franchisees, a third party is involved in the business who can help maintain uniformity in the whole chain in terms of quality 
management, training, and certification. The third party can improve the development and robustness of a franchising chain through training in standardization, quality control, operational support, and certification.

The authors believe that the risks of franchising in this industry are related to the novelty of this idea and lack of real-world performance records which can be overcome through experience. We recommend that further research should be conducted on the readiness and willingness of general contractors to become engaged in energy retrofit services and to adopt the franchising model as a means of rapidly mobilizing their business in this sector. In addition, more detailed research is required to define the components of franchising business model for large-scale energy retrofit projects. To increase customer satisfaction in the proposed franchise structure, building trust among three parties of franchisors, franchisees, and third parties is crucial; therefore, further studies are required on the modeling of trust in the proposed structure to identify fundamental conflicts and propose a practical solution.

\section{Refrences}

Alon, I. (2006). Service franchising: A global perspective. Springer.

Axelrad, N. D., \& House, C. C. (1987). Franchising: A planning and sales compliance guide commerce clearing house.

Botti, L., Briec, W., \& Cliquet, G. (2009). Plural forms versus franchise and company-owned systems: A DEA

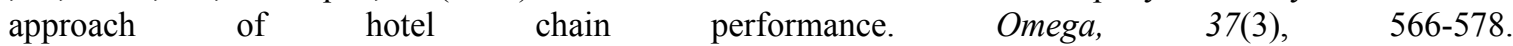
http://dx.doi.org/10.1016/j.omega.2007.12.002

Bradach, J. L. (1998). Franchise organizations. Harvard Business Press.

Brickley, J. A., \& Dark, F. H. (1987). The choice of organizational form the case of franchising. Journal of Financial Economics, 18(2), 401-420. http://dx.doi.org/10.1016/0304-405X(87)90046-8

Building Performance Institute. (2008). BPI accreditation: Policies and procedures. Retrieved July 28, 2011, from http://www.bpi.org/WebDownload/PoliciesandProcedures/BPI_Accreditation_Policies_and_ Procedures_v.2010.5.pdf

Caves, R. E., \& Murphy, W. F. (1976). Franchising: Firms, markets, and intangible assets. Southern Economic Journal, 572-586. http://dx.doi.org/10.2307/1056250

Combs, J. G., Michael, S. C., \& Castrogiovanni, G. J. (2004). Franchising: A review and avenues to greater theoretical diversity. Journal of Management, 30(6), 907. http://dx.doi.org/10.1016/j.jm.2004.06.006

Davies, M. A. P., Lassar, W., Manolis, C., Prince, M., \& Winsor, R. D. (2011). A model of trust and compliance in franchise relationships. Journal of Business Venturing, 26(3), 321-340. http://dx.doi.org/10.1016/j.jbusvent.2009.09.005

Demsetz, H. (1968). Why regulate utilities. The Journal of Law \& Economic, 11, 55. http://dx.doi.org/10.1086/466643

Dongmei, F., \& Xiaoyun, Z. (2009). Construction of franchise project quality risk management system based on project insurance. Paper presented at the Management and Service Science, 2009. MASS'09. International Conference on, 1-5.

Emerson, R. W. (2010). Franchise encroachment. American Business Law Journal, 47(2), 191-290. http://dx.doi.org/10.1111/j.1744-1714.2010.01094.x

Engel, E., Fischer, R., \& Galetovic, A. (1997). Highway franchising: Pitfalls and opportunities. The American Economic Review, 87(2), 68-72.

Entrepreneur. (2011). Franchise zone - buying a franchise. Retrieved May 14, 2011, from http://www.entrepreneur.com/franchises/index.html

Fielding, G. J., \& Klein, D. B. (1993). How to franchise highways. Journal of Transport Economics and Policy, 113-130.

Garg, V. K., \& Rasheed, A. (2006). An explanation of international franchisors' preference for multi-unit franchising. International Journal of Entrepreneurship, 10, 1-20.

Harmon, T. R., \& Griffiths, M. A. (2008). Franchisee perceived relationship value. Journal of Business \& Industrial Marketing, 23(4), 256-263. http://dx.doi.org/10.1108/08858620810865834

Hayek, F. (1978). Competition as a discovery procedure. New Studies in Philosophy, Politics, Economics, and the History of Ideas. Chicago: University of Chicago Press. 
Hollander, J. M., \& Schneider, T. R. (1996). Energy-efficiency: Issues for the decade. Energy, 21(4), 273-287. http://dx.doi.org/10.1016/0360-5442(95)00107-7

Hunt, S. D. (1973). The trend toward company-operated units in franchise chains. Journal of Retailing, 49(2), 3-12.

Kibert, C. J. (2003). Green buildings: An overview of progress. Jounal of Land Use \& Environmental Law, 19 , 491.

McGraw-Hill Construction for US Department of Energy. (2010). Energy efficiency trends in residential and commercial buildings. Retrieved July 31, 2011.

McGraw-Hill Construction. (2010). Energy efficiency trends in residential and commercial buildings. Retrieved from http://apps1.eere.energy.gov/buildings/publications/pdfs/corporate/building_trends_2010.pdf

Michael, S. C. (1996). To franchise or not to franchise: An analysis of decision rights and organizational form shares. Journal of Business Venturing, 11(1), 57-71. http://dx.doi.org/10.1016/0883-9026(95)00088-7

Murray, B., \& Smyth, H. (2009). Barriers to franchise initiation for general contractors in US remodeling industry: A non-franchisor perspective. Paper presented at the ARCOM 2009, 7-9 September, Nottingham.

Murray, B., \& Smyth, H. (2011). Franchising in the US remodelling market: Growth opportunities and barriers faced by general contractors. Construction Management and Economics, 29(6), 623-634. http://dx.doi.org/10.1080/01446193.2011.566622

Oxenfeldt, A. R., \& Kelly, A. O. (1968). Will successful franchise systems ultimately become wholly-owned chains? Journal of Retailing, 44(4), 69-83.

Parker, D. S. (2009). Very low energy homes in the United States: Perspectives on performance from measured data. Energy and Buildings, 41(5), 512-520. http://dx.doi.org/10.1016/j.enbuild.2008.11.017

Smyth, H. (2009). Franchising the supply chain. In S. Pryke (Ed.), Construction supply chain management: Concepts and case studies (pp. 199-211). Malaysia: Wiley Blackwell Pub Ltd.

U.S. Energy Information Administration (EIA). (2010). EIA annual energy review. Retrieved July 29, 2011, from http://www.eia.gov/totalenergy/data/annual/pdf/sec2_4.pdf

US Census Bureau. (2010). USA QuickFacts. Retrieved July 27, 2011, from http://quickfacts.census.gov/qfd/states/00000.html

Watson, A., \& Kirby, D. A. (2000). Explanations of the decision to franchise in a non-traditional franchise sector: The case of the UK construction industry. Journal of Small Business and Enterprise Development, 7(4), 343-351. http://dx.doi.org/10.1108/EUM0000000006850 